\title{
O método e a masculinidade em Virginia Wright Wexman
}

Carmem Filgueiras*

Título: Masculinity in crisis - Method acting in Hollywood in: Movie acting - the film reader.

Autora: Virginia Wright Wexman

Editora: Routledge, Nova lorque

Ano: 2004

Número de páginas: 127-144.

O ponto de partida de Virginia Wexman (Universidade de Princeton) para relacionar o momento de maior aceitação de Stanislavski e a formação de um novo herói cinematográfico é a lendária sugestão que sir Laurence Olivier deu a Dustin Hoffman quando filmavam A maratona da morte (1974). Preocupado com o colega, adepto do Método, que estava vivendo como um maratonista, Olivier perguntou: "Por que não tenta representar?".

Wexman faz um breve balanço da recepção de Stanislavski no cinema americano e afirma que o desejo de realismo levou Hollywood ao Método porque suas técnicas dão ênfase ao que há de próximo entre ator e personagem e delineiam, de modo particular, um novo tipo de herói romântico. $O$ ator do Método busca em sua memória emotiva o sentimento apropriado ao personagem, mas, através de uma técnica de interpretação e por isso, para Wexman, é possível ver tanta artificialidade na atuação de filmes como Uma rua chamada pecado quanto em qualquer outra performance.

Mas, o furor causado pelo Método não foi à toa. Comparadas à escola britânica, outra grande influência do cinema americano, as teorias de Stanislavski levam a uma maior identificação entre ator e personagem, ao invés de incentivarem a audiência a manter certa distância intelectual em relação ao ator. Baseado na busca da verdade interior do ator, o Método faz dele

* Carmen Filgueiras é mestranda em Teatro (UniRio) e pesquisa o uso da noção de jogos de linguagem de Wittgenstein em processos de dramatização. 
um bocado autor e, através de técnicas de improvisação, imaginação, relaxamento e uso da memória afetiva, o intérprete aumenta sua capacidade de apresentar uma ação que pareça viva.

Wexman aponta como, ainda que Stanislavski tenha escrito pensando no teatro, é no cinema que suas idéias são potencializadas. O ator treinado pelo Método não precisa mais ignorar o público, a verdade interior é captada pela câmera antes de se cristalizar em um excesso de encenações teatrais e a interpretação pode manter seu frescor. Além disso, a análise de cenas como partes individuais e emocionalmente auto-referentes facilitam o processo de fazer cinema com suas exigências externas de descontinuidade. Para Wexman, apesar dessas qualidades, o interesse do cinema soviético por Stanislavski não foi desenvolvido porque cineastas como Eisenstein e Pudovkin estavam tomados pela questão da edição dos filmes.

Conforme Wexman, a absorção norte-americana do Método teve que esperar cerca de 30 anos por questões políticas. Entre 1920 e 1930, membros do Teatro de Arte de Moscou imigraram para os Estados Unidos. Mas, o teatro de Alla Nazimova, Richard Boleslavsky e Maria Ouspenskaya continha uma forte preocupação com as frustrações da classe operária, o que não é uma característica muito comercial. Apenas quando Lee Strasberg promulga sua própria versão do Método, através do Actors Studio, Stanislavski é popularizado. Strasberg passa a aumentar a ênfase no caráter psicológico e, conforme a autora, o conceito de improvisação de Stanislavski como modo de criar um senso de comunidade entre os atores se transformou em uma grande celebração da neurose da interpretação individual.

A valorização do ator sobre o personagem segue a necessidade da indústria de produzir astros, ao invés de atores. Wexman afirma que, grosso modo, Strasberg transformou uma teoria igualitária e socialista em uma máquina de fazer celebridades. O curioso é que os três atores mais associados ao Actors não foram exatamente formados por ele: Montgomery Clift nunca fez uma aula no Studio, James Dean assistiu a poucas e parou depois da primeira crítica que Strasberg Ihe fez e Marlon Brando estudou com Stella Adler, que discordava das interpretações que Strasberg fazia de Stanislavski.

Wexman acredita que a associação inapropriada entre o Método e estrelas que não estudaram no Actors Studio estimulou as recentes pesquisas de Richard Dyer (em Stars) e James Naremore (em Acting in the cinema) sobre o que torna uma atuação do Método distinguível. Mas, para a autora, mesmo que não influenciados diretamente por Strasberg, os astros da época adaptaram técnicas do Método para sustentarem uma identificação como rebeldes, transformando-as em clichês, por exemplo, quando o relaxamento 
necessário à criação do papel vira uma postura de desleixo do ator.

Depois de dar o panorama histórico da apropriação do Método por Hollywood, Wexman passa a fazer uma interpretação sobre a construção de um novo tipo de herói possível a partir das sutilezas daquelas técnicas. $\mathrm{O}$ conflito principal de filmes como Juventude Transviada é a dificuldade que o herói rebelde tem para definir sua identidade em relação à figura paterna e o Método tem a habilidade de criar as condições necessárias para dar a uma cena a carga emocional tradicionalmente considerada feminina. Quando James Dean, em Juventude Transviada, diz a seus pais, em um choro angustiado: "vocês estão me fazendo em pedaços!", ele está dando uma nova configuração ao modelo masculino. A criatividade valorizada pelo Método estimula a crença em uma imagem em formação e, assim, o novo herói pode ganhar corpo. Mas, um corpo que ainda precisa da história de amor para dar os termos em que a masculinidade é entendida e avaliada.

Virginia Wexman afirma que, nos últimos anos, a influência do Método na criação da persona do astro tem sido reformulada. No lugar da ansiedade de relações românticas fragmentadas, os atores contemporâneos formados pelo Método, como Robert de Niro, Dustin Hoffman e Al Pacino projetam um frio narcisismo que sugere que eles estão além do romance. Assim, muitos dos filmes de sucesso desses atores tratam da falência do relacionamento romântico, enquanto seus filmes que seguem um roteiro de história de amor tradicional não têm encontrado o mesmo público. Para esses atores, o drama da identidade nem sempre envolve uma relação com uma mulher. Wexman finaliza o artigo afirmando não ser claro como os pensamentos que expôs se relacionam com as mudanças de convenções para o romance e o casamento, mas que, no mundo de comercialização artística que Hollywood é, essas mudanças sempre têm um sentido.

$\mathrm{O}$ artigo de Virginia W. Wexman é singular na qualidade de sintetizar a história da recepção de Stanislavski nos Estados Unidos, mostrando a sua importância na formação do ideal de ator de cinema e de herói de cinema, desde Brando até Hoffman. Além disto, os parágrafos dedicados à atuação de Marlon Brando, em Sindicato de ladrões, são ricos pelas relações traçadas entre as técnicas de interpretação e a formação da estrutura de estilo e de gênero no cinema. 